\title{
FIRE HISTORY OF A GIANT AFRICAN BAOBAB EVINCED BY RADIOCARBON DATING
}

\author{
Adrian Patrut ${ }^{1,2} \bullet$ Diana H Mayne ${ }^{3} \cdot$ Karl F von Reden ${ }^{4,5} \bullet$ Daniel A Lowy ${ }^{6}$ Robert van Pelt ${ }^{7} \cdot$ \\ Ann P McNichol ${ }^{2} \cdot$ Mark L Roberts $^{2} \cdot$ Dragos Margineanu $^{1}$
}

\begin{abstract}
The article reports the first radiocarbon dating of a live African baobab (Adansonia digitata L.), by investigating wood samples collected from 2 inner cavities of the very large 2-stemmed Platland tree of South Africa. Some 16 segments extracted from determined positions of the samples, which correspond to a depth of up to $15-20 \mathrm{~cm}$ in the wood, were processed and analyzed by accelerator mass spectrometry (AMS). Calibrated ages of segments are not correlated with their positions in the stems of the tree. Dating results indicate that the segments originate from new growth layers, with a thickness of several centimeters, which cover the original old wood. Four new growth layers were dated before the reference year AD 1950 and 2 layers were dated post-AD 1950, in the post-bomb period. Formation of these layers was triggered by major damage inside the cavities. Fire episodes are the only possible explanation for such successive major wounds over large areas or over the entire area of the inner cavities of the Platland tree, able to trigger regrowth.
\end{abstract}

\section{INTRODUCTION}

The African baobab (Adansonia digitata L.) is widespread south of the Sahara and generally considered a symbol of Africa (Wickens 1983; Wickens and Lowe 2008). The baobab produces faint growth rings, considered by many researchers to be annual rings (Wickens 1983; Esterhuyse et al. 2001; Robertson et al. 2006). However, these rings cannot be used for dating fallen old baobabs for 2 reasons: i) growth rings may no longer be observed in certain areas of the trunk of old specimens, and ii) the presence of large internal hollows prevents a hypothetically correct ring count. Therefore, the only accurate method for determining the age of African baobabs is radiocarbon dating of wood samples collected from their trunk. According to the published results, only 6 baobabs have been investigated by ${ }^{14} \mathrm{C}$ dating, by using different techniques that have improved over time. The first investigations to determine the age of baobabs employed gas proportional counting (Swart 1963; Robins and Swart 1964; Sheppard and Swart 1971). Recently, Grootboom, a huge baobab that collapsed in Namibia, was dated by means of accelerator mass spectrometry (AMS). It was found to be the oldest known angiosperm tree, with an age of at least $1275 \mathrm{cal} \mathrm{yr}$ (Patrut et al. 2007). Another famous baobab from Namibia was ${ }^{14} \mathrm{C}$ dated by AMS and was found to be over 980 cal yr old (Patrut et al. 2010). Other recent research used ${ }^{14} \mathrm{C}$ dating for determining whether the African baobab can be used as a proxy climate archive (Robertson et al. 2006). Up to the present, the research was limited only to ${ }^{14} \mathrm{C}$ dating of wood samples collected from the remains of dead baobabs, which decay very fast. This fact also accounts for the paucity of research of this type.

The paper reports the first attempt to extend the ${ }^{14} \mathrm{C}$ investigation to standing and live specimens of the African baobab, by dating samples collected from open inner cavities. The obtained results offer new and interesting information about the interaction of the African baobab with the abiotic and biotic environment during its life cycle.

\footnotetext{
${ }^{1}$ Department of Chemistry, Babes-Bolyai University, Arany Janos 11, 400028 Cluj-Napoca, Romania.

${ }^{2}$ Corresponding author. Email: apatrut@gmail.com.

${ }^{3}$ Baobab Trust, Box 1566, Parklands 2121, Johannesburg, South Africa.

${ }^{4}$ NOSAMS Facility, Department of Geology \& Geophysics, Woods Hole Oceanographic Institution, 360 Woods Hole Rd., Mailstop 8, Woods Hole, Massachusetts 02543, USA.

${ }^{5}$ Corresponding author. Email: kvonreden@whoi.edu.

${ }^{6} \mathrm{FlexEl}$, LLC, College Park, Maryland 20742, USA.

${ }^{7}$ College of Forest Resources, Box 352100, University of Washington, Seattle, Washington 98195, USA.
}

C 2010 by the Arizona Board of Regents on behalf of the University of Arizona Proceedings of the 20th International Radiocarbon Conference, edited by A J T Jull RADIOCARBON, Vol 52, Nr 2-3, 2010, p 717-726 


\section{STUDY AREA AND METHODS}

\section{The Platland Tree and Its Area}

The giant Platland tree is located on the Sunland Nursery of Platland farm, $10 \mathrm{~km}$ from the small town of Modjadjiskloof (formerly Duiwelskloof) and $25 \mathrm{~km}$ from Tzaneen, in the Limpopo Province of South Africa. Its GPS coordinates are $23^{\circ} 37.361^{\prime} \mathrm{S}, 030^{\circ} 11.864^{\prime} \mathrm{E}$ and its altitude is $719 \mathrm{~m}$. Mean annual rainfall in the area is $492 \mathrm{~mm}$ (Mooketsi station).

The Platland tree is registered in the South African National Register of Big Trees and included in the South African List of Champion Trees (Department of Water Affairs and Forestry 2006). The tree lies outside its endemic area, so it is considered an exotic specimen by botanists.

The tree has a height of $18.9 \mathrm{~m}$ and a total circumference at breast height (cbh; $1.30 \mathrm{~m}$ above ground level) of $34.00 \mathrm{~m}$. Its footprint of $68.0 \mathrm{~m}^{2}$ (which corresponds to a nominal diameter at ground level of $9.30 \mathrm{~m}$ ) and the cross-sectional area at breast height of $65.3 \mathrm{~m}^{2}$ are the largest known for an African baobab. The trunk consists of 2 stems (I and II), with a cbh of $24.13 \mathrm{~m}$ (stem I) and $18.33 \mathrm{~m}$ (stem II), see Figure 1. These stems are connected by a partially fused section, which has a maximum height of $2.01 \mathrm{~m}$ and covers a shared cbh of $4.10 \mathrm{~m}$.

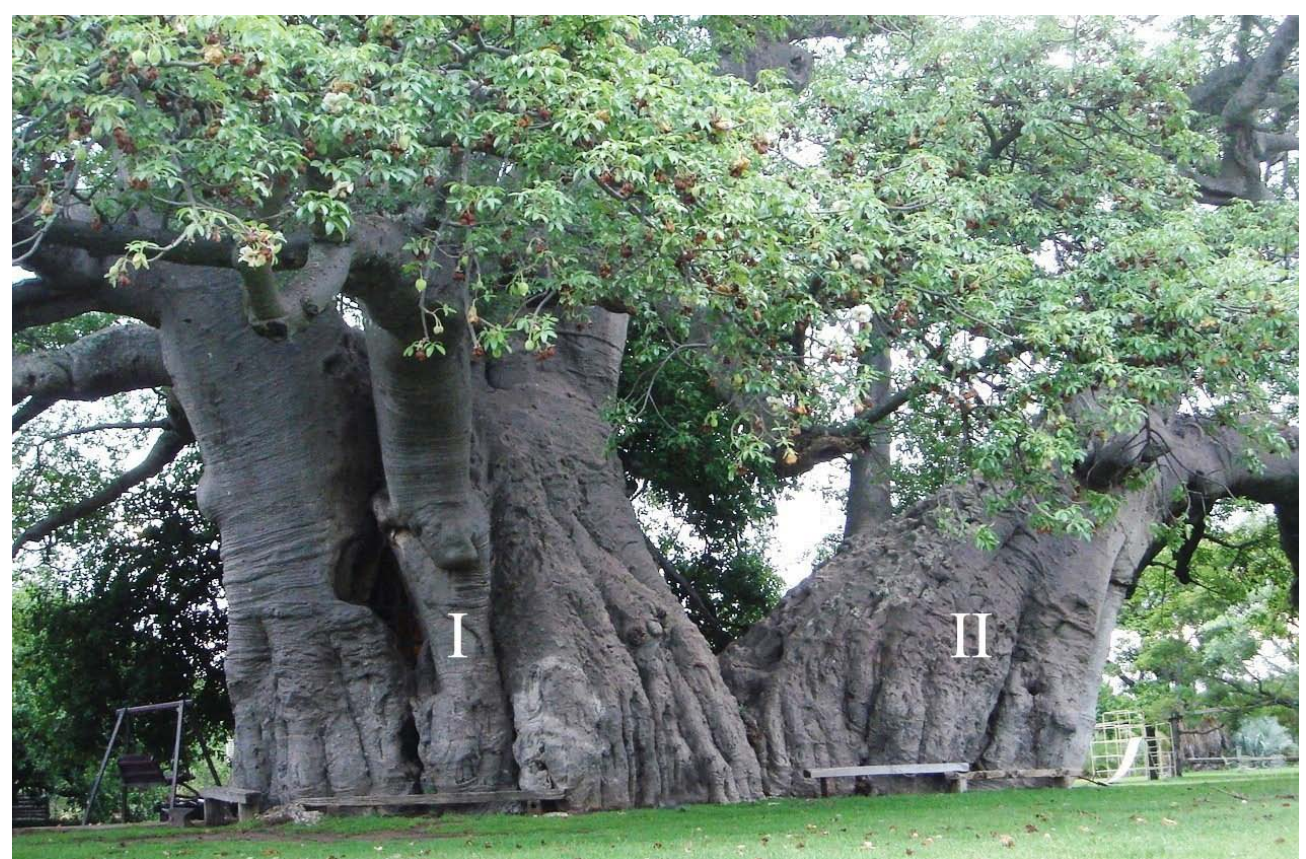

Figure 1 The impressive 2-stemmed trunk of the Platland tree, which is also called Sunland baobab

The large trunk comprises 2 interleading cavities on either side of the fused section; they are about $0.78 \mathrm{~m}$ below the ground level and are connected via a small opening/doorway. The large cavity inside stem I has a maximum length of $4.10 \mathrm{~m}$, a width of $4.50 \mathrm{~m}$, and a height of $4.60 \mathrm{~m}$. The cavity inside stem II has a length of $1.55 \mathrm{~m}$, a width of $2.70 \mathrm{~m}$, and a height of $2.35 \mathrm{~m}$; it also has an elevated extension towards the north, with a length of $2.20 \mathrm{~m}$. The owners of the Platland farm turned the very large cavity inside stem I into a bar and the tree has become heavily promoted under the name Sunland "pub" baobab. 
External measurements of the tree were done by using an inverted Macroscope 25 mounted on a tripod in conjunction with an Impulse 200 laser rangefinder, as well as with the aid of a compass and graduated tapes. Measurements inside cavities were performed with a Bosch DLE 50 Professional digital laser rangefinder.

\section{Sample Collection}

According to our new method of dating samples collected from open inner cavities, several wood samples were collected from different positions of the walls (samples 1,2,3, and 5) and ceiling (samples 4 and 6) of the 2 cavities of the Platland tree (see Figure 2). Samples from the lateral walls were obtained by using a Haglöf CO600 increment borer $(60 \mathrm{~cm}$ long, $0.43 \mathrm{~cm}$ inner diameter). Twenty-cm-long samples were extracted from the ceiling of the cavities with a sharp cutting tool. The projections of sample positions on the cross-section of the trunk are shown in Figure 3.

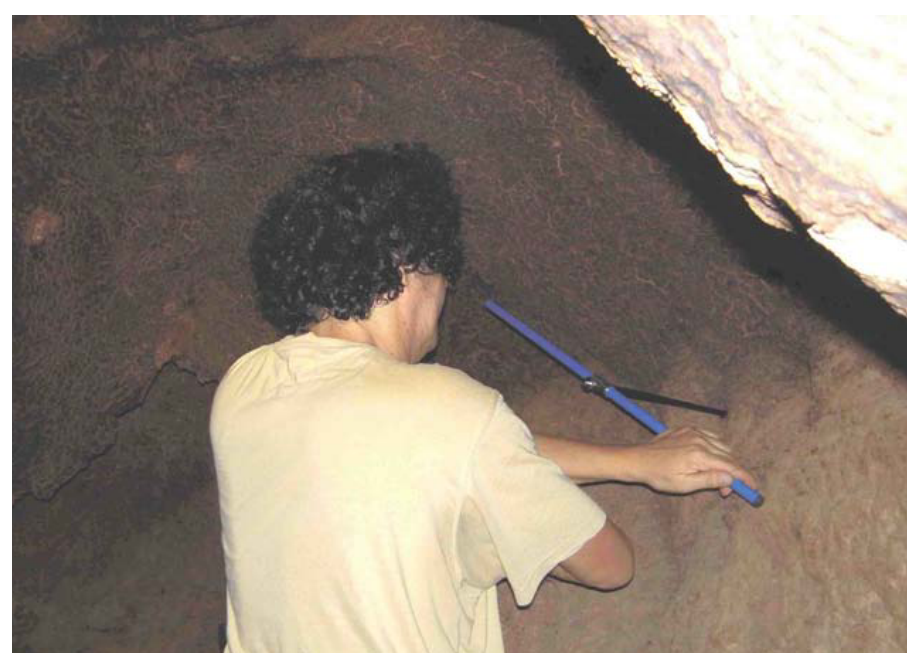

Figure 2 Collecting samples from the inner cavities

This paper focuses on the investigation of 16 segments, which were extracted from determined positions of the original 6 samples. The respective segments, with a length of $1 \mathrm{~cm}$, correspond to a depth of up to $15-20 \mathrm{~cm}$ in the wood. The segments were processed and investigated by AMS ${ }^{14} \mathrm{C}$ dating.

\section{Sample Preparation}

The standard acid-base-acid pretreatment method (Olsson 1986) was used to remove soluble and mobile organic components. The resulting cellulose samples were combusted to $\mathrm{CO}_{2}$ by the closedtube combustion method (Sofer 1980). Then, $\mathrm{CO}_{2}$ was reduced to graphite on iron catalyst, under hydrogen atmosphere (Vogel et al. 1984). Finally, the graphite samples were analyzed by AMS.

\section{AMS Measurements}

${ }^{14} \mathrm{C}$ measurements were carried out at the National Ocean Sciences AMS Facility of the Woods Hole Oceanographic Institution with the Pelletron tandem 500kV AMS system (Roberts et al. 2010) and the Tandetron 3MV AMS system (von Reden et al. 1994). The surface of the graphite samples was sputtered with cesium ions and the secondary negative ions were extracted and accelerated in the AMS system. ${ }^{12} \mathrm{C}$ and ${ }^{13} \mathrm{C}$ ions were measured in Faraday cups, where a ratio of their currents was recorded. ${ }^{14} \mathrm{C}$ ions were collected in a solid state detector, so that ratios of ${ }^{14} \mathrm{C}$ to ${ }^{12} \mathrm{C}$ were also 


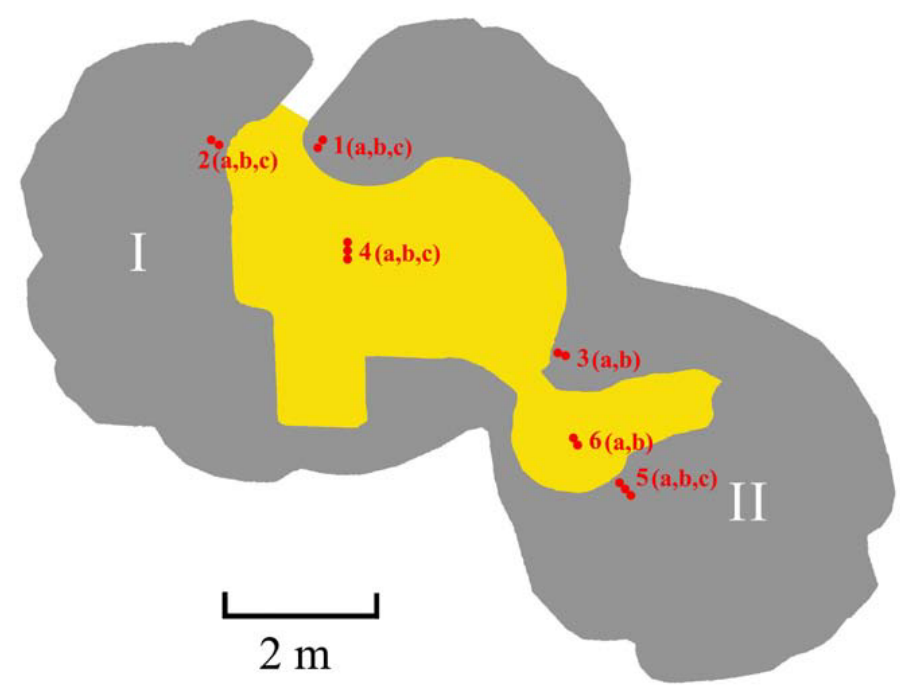

Figure 3 Cross-section of the 2-stemmed trunk, showing the 2 connected cavities and the projections of sample and segment positions.

recorded. These raw signals were compared to ratios obtained with a known standard material (oxalic acid I, NIST-SRM-4990) and converted to a fraction modern (Fm) value, which was corrected for isotopic fractionation with the normalized $\delta^{13} \mathrm{C}$ value of $-25 \%$.

Fm values were ultimately converted to a ${ }^{14} \mathrm{C}$ date. ${ }^{14} \mathrm{C}$ dates and errors were rounded to the nearest year. However, Fm values greater than 1 were not converted into ${ }^{14} \mathrm{C}$ dates, given that this would have yielded irrelevant negative values.

\section{Calibration}

Fm values were calibrated and converted to calendar ages with OxCal v 4.1 for Windows (Bronk Ramsey 1995, 2001), by using comparatively Northern vs. Southern Hemisphere data sets, in order to verify the influence of the Intertropical Convergence Zone on regional/local ${ }^{14} \mathrm{C}$ concentration. For 8 segments showing values Fm $>1$, corresponding theoretically to negative ${ }^{14} \mathrm{C}$ dates, the Postbomb atmospheric NH zone 3 and Post-bomb atmospheric SH data sets (Hua and Barbetti 2004) were employed. The 8 segments with values $\mathrm{Fm}<1$, corresponding to positive ${ }^{14} \mathrm{C}$ dates, were calibrated with the IntCal04 (Reimer et al. 2004a) and SHCal04 (McCormac et al. 2004) atmospheric data sets. In the text, ${ }^{14} \mathrm{C}$ dates/uncalibrated ages are reported as ${ }^{14} \mathrm{C}$ yr BP or simply BP, while calibrated ages are provided as cal yr or AD.

\section{RESULTS AND DISCUSSION}

\section{AMS Results and Calibrated Ages}

The 16 investigated segments, which were labeled a, b, and c, originate from the total of 6 wood samples numbered 1 to 6 , as follows: 2 each from samples 3 and 6 , and 3 each from samples 1, 2, 4, and 5. The AMS dating results and calibrated ages are listed in Table 1. For all sample segments, the $1-\sigma$ probability distribution (corresponding to the $68.3 \%$ confidence interval) was selected for deriving calibrated age ranges. Each $1-\sigma$ probability distribution (with the exception of segments $1 b, 4 b$ ) corresponds to several ranges of calendar years. 
Table 1 AMS ${ }^{14} \mathrm{C}$ dating results and calibrated ages.

\begin{tabular}{|c|c|c|c|c|c|}
\hline $\begin{array}{l}\text { Segment code [stem] } \\
\text { (NOSAMS } \\
\text { accession } \mathrm{nr} \text { ) }\end{array}$ & $\begin{array}{l}\text { Depth }^{\mathrm{a}} \\
\left.\text { [height }^{\mathrm{b}}\right] \\
\left(10^{-2} \mathrm{~m}\right)\end{array}$ & $\begin{array}{l}\text { Fraction } \\
\text { modern } \\
\text { [error] }\end{array}$ & $\begin{array}{l}{ }^{14} \mathrm{C} \text { date } \\
\text { [error] } \\
\left({ }^{14} \mathrm{C} \text { yr } \mathrm{BP}\right)\end{array}$ & $\begin{array}{l}\text { Calibration } \\
\text { curve }\end{array}$ & $\begin{array}{l}\text { Cal AD range(s) } \\
1-\sigma \\
{[\text { confidence interval] }}\end{array}$ \\
\hline \multirow{2}{*}{$\begin{array}{l}\text { 1a [I] } \\
(\text { OS-61159) }\end{array}$} & \multirow{2}{*}{$\begin{array}{c}8-9 \\
{[130]}\end{array}$} & \multirow{2}{*}{$\begin{array}{l}1.1220 \\
{[ \pm 0.0040]}\end{array}$} & \multirow[t]{2}{*}{-} & Bomb04 NH3 & 1993-1995 [68.2\%] \\
\hline & & & & Bomb04 SH & $1994-1996[68.2 \%]$ \\
\hline $\begin{array}{l}\text { 1b [I] } \\
(\text { OS-67077) }\end{array}$ & $\begin{array}{l}13-14 \\
{[130]}\end{array}$ & $\begin{array}{l}1.0151 \\
{[ \pm 0.0022]}\end{array}$ & - & $\begin{array}{l}\text { Bomb04 NH3 } \\
\text { Bomb04 SH }\end{array}$ & $\begin{array}{l}1955-1957[68.2 \%] \\
1956[68.2 \%]\end{array}$ \\
\hline \multirow[t]{2}{*}{$\begin{array}{l}\text { 1c [I] } \\
(\mathrm{OS}-76795)\end{array}$} & \multirow[t]{2}{*}{$\begin{array}{l}19-20 \\
{[130]}\end{array}$} & \multirow[t]{2}{*}{$\begin{array}{l}0.9633 \\
{[ \pm 0.0033]}\end{array}$} & \multirow[t]{2}{*}{$300[ \pm 27]$} & IntCal04 & $\begin{array}{l}1522-1575[46.6 \%] \\
1584-1590[3.8 \%] \\
1625-1646[17.7 \%]\end{array}$ \\
\hline & & & & SHCal04 & $\begin{array}{l}1515-1541[19.1 \%] \\
1625-1660[49.1 \%]\end{array}$ \\
\hline \multirow[t]{2}{*}{$\begin{array}{l}\text { 2a [I] } \\
(\text { OS-62009) }\end{array}$} & \multirow[t]{2}{*}{$\begin{array}{l}7-8 \\
{[90]}\end{array}$} & \multirow[t]{2}{*}{$\begin{array}{l}1.1360 \\
{[ \pm 0.0037]}\end{array}$} & \multirow[t]{2}{*}{-} & Bomb04 NH3 & $\begin{array}{l}1958[5.2 \%] \\
1991-1993[63.1 \%]\end{array}$ \\
\hline & & & & Bomb04 SH & $\begin{array}{l}1959[8.4 \%] \\
1990[6.9 \%] \\
1992-1994[52.9 \%]\end{array}$ \\
\hline \multirow[t]{2}{*}{$\begin{array}{l}\mathbf{2 b}[\mathbf{I}] \\
(\mathrm{OS}-67043)\end{array}$} & \multirow[t]{2}{*}{$\begin{array}{l}14-15 \\
{[90]}\end{array}$} & \multirow[t]{2}{*}{$\begin{array}{l}0.9746 \\
{[ \pm 0.0024]}\end{array}$} & \multirow[t]{2}{*}{$207[ \pm 19]$} & IntCal04 & $\begin{array}{l}1658-1673[19.0 \%] \\
1778-1799[33.4 \%] \\
1942-1953[15.8 \%]\end{array}$ \\
\hline & & & & SHCal04 & $\begin{array}{l}1670-1682[11.1 \%] \\
1731-1783[50.7 \%] \\
1795-1802[6.4 \%]\end{array}$ \\
\hline \multirow[t]{2}{*}{$\begin{array}{l}\text { 2c [I] } \\
(\text { OS-71902) }\end{array}$} & \multirow[t]{2}{*}{$\begin{array}{l}18-19 \\
{[90]}\end{array}$} & \multirow[t]{2}{*}{$\begin{array}{l}0.9625 \\
{[ \pm 0.0041]}\end{array}$} & \multirow[t]{2}{*}{$307[ \pm 33]$} & IntCal04 & $\begin{array}{l}1521-1592[51.2 \%] \\
1620-1644[17.0 \%]\end{array}$ \\
\hline & & & & SHCal04 & $\begin{array}{l}1511-1552[28.1 \%] \\
1558-1573[8.1 \%] \\
1622-1655[32.0 \%]\end{array}$ \\
\hline \multirow[t]{2}{*}{$\begin{array}{l}\text { 3a [I] } \\
(\mathrm{OS}-62011)\end{array}$} & \multirow[t]{2}{*}{$\begin{array}{c}7-8 \\
{[50]}\end{array}$} & \multirow[t]{2}{*}{$\begin{array}{l}1.1703 \\
{[ \pm 0.0040]}\end{array}$} & \multirow[t]{2}{*}{ - } & Bomb04 NH3 & $\begin{array}{l}1958[3.8 \%] \\
1988-1989[64.4 \%]\end{array}$ \\
\hline & & & & Bomb04 SH & $\begin{array}{l}1960[6.9 \%] \\
1988-1991[61.3 \%]\end{array}$ \\
\hline \multirow[t]{2}{*}{$\begin{array}{l}\text { 3b [I] } \\
(\text { OS-67070) }\end{array}$} & \multirow[t]{2}{*}{$\begin{array}{l}14-15 \\
{[50]}\end{array}$} & \multirow[t]{2}{*}{$\begin{array}{l}0.9898 \\
{[ \pm 0.0029]}\end{array}$} & \multirow[t]{2}{*}{$82[ \pm 23]$} & IntCal04 & $\begin{array}{l}1699-1722[20.1 \%] \\
1818-1833[13.3 \%] \\
1880-1916[34.8 \%]\end{array}$ \\
\hline & & & & SHCal04 & $\begin{array}{l}1816-1829[23.4 \%] \\
1892-1921[44.8 \%]\end{array}$ \\
\hline \multirow{2}{*}{$\begin{array}{l}\mathbf{4 a}[\mathbf{I}] \\
(\mathrm{OS}-61322)\end{array}$} & $7-8$ & 1.1752 & - & Bomb04 NH3 & $1987-1989$ [68.2\%] \\
\hline & {$[375]$} & {$[ \pm 0.0046]$} & & Bomb04 SH & $\begin{array}{l}1959[5.2 \%] \\
1960[12.0 \%] \\
1987[12.4 \%] \\
1988-1990[38.7 \%]\end{array}$ \\
\hline $4 b[I]$ & $12-13$ & 1.0104 & - & Bomb04 NH3 & $1954-1956[68.2 \%]$ \\
\hline (OS-61982) & {$[380]$} & {$[ \pm 0.0042]$} & & Bomb04 SH & $1955-1957[68.2 \%]$ \\
\hline $\begin{array}{l}\text { 4c [I] } \\
(\text { OS-67071) }\end{array}$ & $\begin{array}{l}18-19 \\
{[386]}\end{array}$ & $\begin{array}{l}0.9756 \\
{[ \pm 0.0028]}\end{array}$ & $198[ \pm 23]$ & IntCal04 & $\begin{array}{l}1661-1680[18.1 \%] \\
1764-1800[34.5 \%] \\
1939-1953[15.6 \%]\end{array}$ \\
\hline & & & & SHCal04 & $\begin{array}{l}1669-1694[18.4 \%] \\
1726-1784[41.1 \%] \\
1795-1807[8.7 \%]\end{array}$ \\
\hline 5a [II] & $6-7$ & 1.1237 & - & Bomb04 NH3 & $1993-1995[68.2 \%]$ \\
\hline (OS-67082) & {$[40]$} & {$[ \pm 0.0026]$} & & Bomb04 SH & $1994-1996$ [68.2\%] \\
\hline $\begin{array}{l}\mathbf{5 b}[\mathbf{I I}] \\
(\mathrm{OS}-67821)\end{array}$ & $\begin{array}{l}12-13 \\
{[40]}\end{array}$ & $\begin{array}{l}0.9900 \\
{[ \pm 0.0036]}\end{array}$ & $80[ \pm 29]$ & IntCal04 & $\begin{array}{l}1697-1725[21.0 \%] \\
1815-1835[14.9 \%] \\
1878-1915[32.3 \%]\end{array}$ \\
\hline & & & & SHCal04 & $\begin{array}{l}1712-1719[4.3 \%] \\
1813-1836[24.1 \%] \\
1891-1923[39.8 \%]\end{array}$ \\
\hline
\end{tabular}


Table 1 AMS ${ }^{14} \mathrm{C}$ dating results and calibrated ages. (Continued)

\begin{tabular}{|c|c|c|c|c|c|}
\hline $\begin{array}{l}\text { Segment code [stem] } \\
\text { (NOSAMS } \\
\text { accession nr) }\end{array}$ & $\begin{array}{l}\text { Depth }^{\mathrm{a}} \\
\left.\text { [height }^{\mathrm{b}}\right] \\
\left(10^{-2} \mathrm{~m}\right)\end{array}$ & $\begin{array}{l}\text { Fraction } \\
\text { modern } \\
\text { [error] }\end{array}$ & $\begin{array}{l}{ }^{14} \mathrm{C} \text { date } \\
\text { [error] } \\
\left({ }^{14} \mathrm{C} \text { yr BP }\right)\end{array}$ & $\begin{array}{l}\text { Calibration } \\
\text { curve }\end{array}$ & $\begin{array}{l}\text { Cal AD range(s) } \\
1-\sigma \\
{[\text { confidence interval }]}\end{array}$ \\
\hline \multirow[t]{2}{*}{$\begin{array}{l}\mathbf{5 c}[\mathrm{II}] \\
(\mathrm{OS}-62013)\end{array}$} & \multirow[t]{2}{*}{$\begin{array}{l}18-19 \\
{[40]}\end{array}$} & \multirow[t]{2}{*}{$\begin{array}{l}0.9761 \\
{[ \pm 0.0036]}\end{array}$} & \multirow[t]{2}{*}{$194[ \pm 29]$} & IntCal04 & $\begin{array}{l}1663-1681[16.7 \%] \\
1739-1744[3.3 \%] \\
1763-1802[34.4 \%] \\
1938-1952[13.8 \%]\end{array}$ \\
\hline & & & & SHCal04 & $\begin{array}{l}1669-1699[17.5 \%] \\
1723-1785[33.3 \%] \\
1794-1809[8.4 \%] \\
1839-1844[2.0 \%] \\
1868-1877[3.7 \%] \\
1934-1937[1.1 \%] \\
1946-1951[2.2 \%]\end{array}$ \\
\hline \multirow[t]{2}{*}{$\begin{array}{l}\text { 6a [II] } \\
(\mathrm{OS}-62012)\end{array}$} & \multirow[t]{2}{*}{$\begin{array}{l}7-8 \\
{[227]}\end{array}$} & \multirow[t]{2}{*}{$\begin{array}{l}1.1709 \\
{[ \pm 0.0034]}\end{array}$} & \multirow[t]{2}{*}{-} & Bomb04 NH3 & $\begin{array}{l}1958[4.1 \%] \\
1988-1989[64.1 \%]\end{array}$ \\
\hline & & & & Bomb04 SH & $\begin{array}{l}1960[8.4 \%] \\
1988-1990[59.8 \%]\end{array}$ \\
\hline \multirow[t]{2}{*}{$\begin{array}{l}\text { 6b [II] } \\
(\text { OS-62014) }\end{array}$} & \multirow[t]{2}{*}{$\begin{array}{l}13-14 \\
{[233]}\end{array}$} & \multirow[t]{2}{*}{$\begin{array}{l}0.9683 \\
{[ \pm 0.0036]}\end{array}$} & \multirow[t]{2}{*}{$259[ \pm 29]$} & IntCal04 & $\begin{array}{l}1530-1538[5.9 \%] \\
1635-1666[51.5 \%] \\
1784-1796[10.8 \%]\end{array}$ \\
\hline & & & & SHCal04 & $\begin{array}{l}1644-1672[36.7 \%] \\
1745-1755[8.6 \%] \\
1764-1770[4.8 \%] \\
1780-1797[18.1 \%]\end{array}$ \\
\hline
\end{tabular}

${ }^{a}$ Depth in the wood from the cavity wall/ceiling.

${ }^{b}$ Height above cavity level (which is $0.78 \mathrm{~m}$ under ground level)

The cal age ranges of the investigated segments correspond to lower calendar age values than expected from their positions in the stems of the tree. Eight segments were found to be very young, showing ages greater than Modern, which fall after the reference year AD 1950, in the so-called post-bomb period (Reimer et al. 2004b). This indicates that all dated wood of the 16 sample segments, which correspond to a depth of up to $15-20 \mathrm{~cm}$, originate from different layers of new growth/regrowth and not from the original old wood of the respective positions.

\section{Origin of New Growth Layers}

Adansonia species are not only tropical stem-succulent trees, able to store large amounts of water in their trunk, but also sapwood trees, which do not form heartwood (Fisher 2001). Like other sapwood trees, baobabs exhibit self-healing ability deep within the stem and also in their large internal cavities (Ng 1986).

The new growth layers from the sample segments of the Platland tree are a consequence of repairing the interior xylem after substantial wood damage inside the cavities. The wood in baobab stems is comprised mainly of parenchyma tissue, much of which remains alive for a long time and at significant depths into trunk. Baobab wood contains a greater proportion of parenchyma cells in its trunk (69-88\% by volume) than any other investigated tree species (Chapotin et al. 2006). Therefore, its original old wood, i.e. old secondary xylem, contains xylem parenchyma that is alive. As a consequence, the old dead vessels and xylem fibers have adjacent metabolically active parenchyma cells. The repair of the damaged interior xylem is a result of wound callus production by the division of living parenchyma cells, just below the affected wood surface. It can be associated with the wound healing by exposed secondary xylem, observed on the surface of branches of an African baobab, which were transversely cut (Fisher 1981). Regrowth from damage is common in the species. 
Dating results of the investigated segments document the presence of 6 new growth layers inside the cavities of the Platland tree, which cover the original old wood. These new growth layers inside the cavities represent a response of the baobab to its interaction with abiotic and biotic factors in the environment, which could inflict injuries and wounds. Three of the regenerated secondary xylem layers were identified in both cavities from the cavity level up to the ceiling. Fire damage is the only reasonable explanation for such successive major wounds over large areas or even over the entire area of the internal cavities of the Platland tree, which may trigger regrowth.

In the investigated samples, the successive regrowth layers reach a maximum depth in the range from about $15 \mathrm{~cm}$ (samples 3 and 6) to $20 \mathrm{~cm}$ (samples 1, 2, 4 and 5); the initial old wood corresponding to the respective positions in the stems is located at greater depths, below the regrowth layers. Dating results of old wood segments, corresponding to depths values greater than $15-20 \mathrm{~cm}$ in the wood of inner cavities, which are not provided in this article, indicate that the 2 stems (I and II) of the Platland tree are independent and fused completely up to a height of $\sim 2 \mathrm{~m}$ over $450 \mathrm{cal}$ yr ago.

\section{Dates of New Growth Layers}

As emphasized previously, the only possible explanation for the 6 new growth/regrowth layers is that they were triggered by 6 major fires, which affected the cavities of the Platland tree. Ages of regrowth layers allowed determining the dates when these fires occurred. Four regrowth layers were dated before the reference year AD 1950, i.e. BP (before present), while 2 regrowth layers were dated post-AD 1950, in the post-bomb period.

- a) Post-AD 1950 regrowth layers. The most recent 2 regrowth layers and the corresponding fires were dated after the reference year AD 1950, in the post-bomb period.

The regrowth layer of $A D$ 1990. The first segment of each of the 6 collected samples (1a, 2a, 3a, $4 \mathrm{a}, 5 \mathrm{a}, 6 \mathrm{a})$, corresponding to a depth of up to about $7-9 \mathrm{~cm}$ in the wood, was dated around AD 1990 and after this year. We can state that with confidence, because the fire episode of 1990 is well known and was generated by human activity. It is obvious that the youngest new growth layer, i.e. the shallowest, was subsequent to the fire of 1990, the regrowth being triggered by the combustion. This regrowth is at least $9 \mathrm{~cm}$ at the location of sample 1, indicating that the new wood layer initiated by fire has experienced a growth burst of several years.

The regrowth layer of around $A D$ 1955. The second segment of 2 samples originating from the large cavity inside stem I $(1 \mathrm{~b}, 4 \mathrm{~b})$, which corresponds to a depth of $12-14 \mathrm{~cm}$ in the wood, was dated around AD 1955. The respective regrowth layer was not identified in samples collected from the cavity inside stem II.

- b) Regrowth layers before AD 1950. The oldest 4 regrowth layers and the corresponding fires were dated BP (before present), i.e. before the reference year AD 1950. For each regrowth layer, we provided a cal age range for each data set, which corresponds to the set-theoretic union of the $1-\sigma$ ranges with the highest probability for the corresponding ${ }^{14} \mathrm{C}$ dates. This is only a working model and other cal age ranges, with lower probabilities, cannot be excluded.

The regrowth layer of around $80 \mathrm{BP}$. Two segments (3b, 5b), corresponding to a depth of 12-15 $\mathrm{cm}$ in the wood, were dated $80 \pm 29$ and $82 \pm 23 \mathrm{BP}$. The respective ${ }^{14} \mathrm{C}$ dates correspond to a $1-\sigma$ age range of AD 1878-1916 when using the IntCal04 data set, and AD 1891-1923 with the SHCal04 data set.

The regrowth layer of around $200 \mathrm{BP}$. The other 3 segments (2b, 4c, 5c), which correspond to a depth of $14-19 \mathrm{~cm}$ in the wood, were ${ }^{14} \mathrm{C}$ dated around $200 \mathrm{BP}$, more precisely $194 \pm 29,198 \pm$ 23, and $207 \pm 19 \mathrm{BP}$. These ${ }^{14} \mathrm{C}$ dates correspond to a 1- $\sigma$ age range of AD 1763-1802 with the IntCal04 data set, and AD 1723-1785 with the SHCal04 data set. 
The regrowth layer of around $260 \mathrm{BP}$. One segment from the cavity inside stem II (6b), which originates from a depth of 13-14 cm in the wood, was dated $259 \pm 29$ BP. It corresponds to a 1$\sigma$ age range of AD 1635-1666 when using the IntCal04 data set, and AD 1644-1672 with the SHCal04 data set.

The regrowth layer of around $300 \mathrm{BP}$. Two segments form the cavity inside stem I (1c, 2c), which correspond to a depth of $18-20 \mathrm{~cm}$ in the wood, were ${ }^{14} \mathrm{C}$ dated to $300 \pm 27$ and $307 \pm 33$ BP. These dates correspond to a $1-\sigma$ age range of AD 1521-1592 with the IntCal04 data set, and AD 1622-1660 with the SHCal04 data set.

One should note that in none of the 6 collected samples could all 6 regrowth layers be identified. We found a maximum of 3 regrowth layers in samples 1,2, 4, and 5. Only the youngest layer, triggered by the latest fire of AD 1990, was identified in all 6 samples. These findings are the consequences of several aspects: i) each new growth layer, except for the youngest one, was partially or totally combusted by a subsequent fire inside the cavity; therefore, it is possible that certain regrowth layers from the location of several samples were completely or almost completely charred by the next fire; ii) the fire may not affect equally the entire surface of cavities and, therefore, the thickness of a certain growth layer in the walls of cavities is variable; iii) the youngest regrowth layer, formed after the very big fire of AD 1990, is also the thickest and it was identified in all samples, given that there were no subsequent fire events that would have burned it (partially or totally); iv) it is also possible that some thin regrowth layers from certain samples were not revealed, in the absence of a point-bypoint analysis.

\section{Northern vs. Southern Hemisphere Calibration}

Fraction modern (Fm) values were calibrated by using comparatively Northern vs. Southern Hemisphere data sets. As expected, age differences when using these 2 calibration data sets are small.

A comparative calibration might be of interest especially for samples with values $\mathrm{Fm}<1$, corresponding to the oldest 4 regrowth layers, for which the IntCal04 and SHCal04 data sets were used. The Southern Hemisphere atmospheric calibration curves, i.e. SHCal02 and SHCal04, were derived from the general IntCal98 and IntCal04 data sets, by using measurements on contemporaneous Northern and Southern Hemisphere sample pairs. These measurements suggest a variable interhemispheric offset of several decades over the time span covered by the calibration curves (McCormac et al. 2002, 2004). However, the utilized SHCal04 data set does not contain information for low southern latitudes and includes only a few results for a short time period from South Africa, due also in part to the absence of native conifers in Africa.

For the investigated segments, the comparative calibration leads to an offset of 1 to 4 decades for 3 regrowth layers that were dated before AD 1950. For 2 segments (1c, 2c) that correspond to the oldest regrowth layer of around $300 \mathrm{BP}$, the offset is greater, of 7 to 10 decades, due to "wiggles" in the calibration curves. Consequently, when using the SHCal04 calibration, the 1- $\sigma$ cal age ranges for the 2 oldest regrowth layers from around 260 and 300 BP overlap in part.

In the absence of a reliable sequence of growth rings for large and hollow baobabs, such as the Platland tree, and as no old written records exist for Africa, it was not possible to make a choice between the 2 data sets based on the accuracy of the presented comparative results.

\section{Origin of Fires}

In the arid areas around the Limpopo Basin, there is generally little build-up of biomass to fuel intense fires. Also, large baobabs with broad canopies generally have little grass cover, therefore, are 
less threatened (Nel 1988). However, due to high rainfall episodes during the rainy season, often mentioned in the Platland tree area, fuel loads or the build-up of green biomass becomes a more relevant factor, as does the season of fire and the prevailing weather conditions (Govender et al. 2006).

The most recent fire episode of AD 1990 is documented and was inflicted by human activity. Workers at the farm set a fire to smoke out a pair of black mamba snakes from the cavities. The fire got out of control and burned badly the inner cavities of the Platland tree. The other fire episodes evinced by the dating results could have been caused by a number of factors, such as natural veld fires ignited by lightning or by drought and excessive heat; anthropogenic veld fires caused by hunting practices, namely to stimulate early grazing; or fires started through honey gathering and as protection against wild animals at the entrance of the cavities.

Artifacts found in the cavities indicate that the Platland tree was possibly used for centuries as a shelter. The tree was along one of the old, possibly ancient ivory and gold trading routes through the region. The other 5 fire episodes within the cavities of the Platland tree could have been generated by abiotic factors (build up of biomass, possibly aided by lightning to fuel intense fires to burn also the internal cavities, natural veld fires) or biotic factors (human activity). On the basis of current field observations in Southern Africa for both abiotic and biotic causes and the archaeological and historic record, fires caused by human activity appear to be more likely.

\section{CONCLUSIONS}

The research reported here represents the first attempt of dating a live and standing baobab tree, by investigating wood samples collected from open inner cavities. AMS analysis of sample segments collected from the cavities of the Platland tree led to the following conclusions:

1. Any sizeable fire damage in the open cavity of a baobab immediately triggers a significant new growth. New growth can be several centimeters thick and covers the entire damaged cavity area.

2. Each new growth layer is partially (or totally) combusted by a subsequent fire inside the cavity; this causes further growth, yielding 1 additional young wood coating layer inside the cavity.

3. AMS results indicate that a depth of $15-20 \mathrm{~cm}$ in the wood inside cavities is not sufficient for reaching the original old wood of large baobabs with multiple fire episodes;

4. Dating results document 6 new growth layers in the cavities of the Platland tree. Ages of successive new growth layers allowed determining the dates when the corresponding fires occurred.

5. Age differences when using different calibration data sets for Northern and Southern hemispheres are small, with the exception of segments that correspond to the oldest new growth layer.

Results reported in this paper demonstrate that the ${ }^{14} \mathrm{C}$ dating method is suitable for evincing successive fire episodes suffered by the African baobab. This new approach is very promising for documenting, in a reliable manner, past environmental events in remote zones, lacking written records.

\section{ACKNOWLEDGMENTS}

We would like to thank Heather and Doug van Heerden, the owners of Sunland Nursery, as well as Jack Fisher, Dan Rus-Staroste, Codruta and Grigore Bojescu, Eugene Gergely for providing valuable help and useful discussions. This material is based on work supported by a grant from the Romanian National University Research Council (PN II - IDEI 2354 Nr. 1092) and by US National Science Foundation under Cooperative Agreement OCE-022828996. 


\section{REFERENCES}

Bronk Ramsey C. 1995. Radiocarbon calibration and analysis of stratigraphy: the OxCal program. Radiocarbon 37(2):425-30.

Bronk Ramsey C. 2001. Development of the radiocarbon calibration program. Radiocarbon 43(2A):355-63.

Chapotin SM, Razanameharikaza JH, Holbrook NM. 2006. A biomechanical perspective on the role of large stem volume and high water content in baobab trees (Adansonia spp.; Bombacaceae). American Journal of Botany 93(9):1251-64.

Department of Water Affairs and Forestry (South Africa). 2006. List of Champion Trees. URL: http:// www2.dwaf.gov.za/webapp/SustainableChampionTrees.aspx.

Esterhuyse N, von Breitenbach J, Söhnge H. 2001. Remarkable Trees of South Africa. Pretoria: Briza. p 157-8.

Fisher JB. 1981. Wound healing by exposed secondary xylem in Adansonia (Bombacaceae). IAWA Bulletin 2(4):193-9.

Fisher JB. 2001. Secrets of the Tree Trunks. Garden Views (Fairchild Garden) 43:8-10.

Govender N, Trollope WSW, van Wilgen BV. 2006. Effect of fire season, fire frequency, rainfall and management on fire intensity in savanna vegetation in South Africa. Journal of Applied Ecology 43(4):748-58.

Hua Q, Barbetti M. 2004. Review of tropospheric bomb ${ }^{14} \mathrm{C}$ data for carbon cycle modeling and age calibration purposes. Radiocarbon 46(3):1273-98.

McCormac FG, Reimer PJ, Hogg AG, Higham TFG, Baillie MGL, Palmer J, Stuiver M. 2002. Calibration of the radiocarbon time scale for the Southern Hemisphere: AD 1850-950. Radiocarbon 44(3):641-51.

McCormac FG, Hogg AG, Blackwell PG, Buck CE, Higham TFG, Reimer PJ. 2004. SHCal04 Southern Hemisphere calibration, 0-11.0 cal kyr BP. Radiocarbon 46(3):1087-92.

Nel PJ. 1988. Kremetartbome in die Nasionale Wildtuin [internal memorandum]. Skukuza: National Parks.

Ng FSP. 1986. Tropical sapwood trees. Naturalia Monspeliensia. Colloque International sur l'arbre, Montpellier, France. p 61-97.

Olsson IU. 1986. Radiometric methods. In: Berglund B, editor. Handbook of Holocene Palaeoecolgy and Palaeohydrology. Chichester: Wiley. p 273-312.

Patrut A, von Reden K, Lowy DA, Alberts AH, Pohlman JW, Wittmann R, Gerlach D, Xu L, Mitchell CS. 2007. Radiocarbon dating of a very large African baobab. Tree Physiology 27(11):1569-74.
Patrut A, von Reden K, Lowy DA, Mayne DH, Elder KE, Roberts ML, McNichol AP. 2010. Comparative AMS radiocarbon dating of pretreated versus non-pretreated tropical wood samples. Nuclear Instruments and Methods in Physics Research B 268(7-8):910-3.

Reimer PJ, Baillie MGL, Bard E, Bayliss A, Beck JW, Bertrand CJH, Blackwell PG, Buck CE, Burr GS, Cutler KB, Damon PE, Edwards RL, Fairbanks RG, Friedrich M, Guilderson TP, Hogg AG, Hughen KA, Kromer B, McCormac G, Manning S, Bronk Ramsey C, Reimer RW, Remmele S, Southon JR, Stuiver M, Talamo S, Taylor FW, van der Plicht J, Weyhenmeyer CE. 2004a. IntCal04 terrestrial radiocarbon age calibration, 0-26 cal kyr BP. Radiocarbon 46(3):1029-58.

Reimer PJ, Brown TA, Reimer RW. 2004b. Discussion: reporting and calibration of post-bomb ${ }^{14} \mathrm{C}$ data. $R a$ diocarbon 46(3):1299-304.

Roberts ML, Burton JR, Elder KL, Longworth BE, McIntyre CP, von Reden KF, Han BX, Rosenheim BE, Jenkins WJ, Galutschek E, McNichol AP. 2010. A high-performance ${ }^{14} \mathrm{C}$ accelerator mass spectrometry system. Radiocarbon 52(2-3):228-35.

Robertson J, Loader NJ, Froyd CA, Zambatis N, Whyte I, Woodborne S. 2006. The potential of the baobab (Adansonia digitata L.) as a proxy climate archive. Applied Geochemistry 21(10):1674-80.

Robins PA, Swart ER. 1964. Southern Rhodesian radiocarbon measurements I. Radiocarbon 6(1):31-6.

Sheppard JG, Swart ER. 1971. Rhodesian radiocarbon measurements IV. Radiocarbon 13(2):420-31.

Sofer Z. 1980. Preparation of carbon dioxide for stable carbon isotope analysis of petroleum fractions. Analytical Chemistry 52(8):1389-91.

Swart ER. 1963. Age of the baobab tree. Nature 198(4881):708-9.

Vogel JS, Southon JR, Nelson DE, Brown TA. 1984. Performance of catalytically condensed carbon for use in accelerator mass spectrometry. Nuclear Instruments and Methods in Physics Research B 5(2):289-93.

von Reden KF, Schneider RJ, Cohen GJ, Jones GA. 1994. Performance characteristics of the 3 MV Tandetron AMS system at the National Ocean Sciences AMS facility. Nuclear Instruments and Methods in Physics Research B 92(1-4):7-11.

Wickens GE. 1983. The baobab: Africa's upside-down tree. Kew Bulletin 37(2):173-209.

Wickens GE, Lowe P. 2008. The Baobabs: Pachycauls of Africa, Madagascar and Australia. Dordrecht: Springer. $498 \mathrm{p}$ 